\title{
Identifying Leafhopper Targets for Controlling Aster Yellows in Carrots and Celery
}

\author{
Patrick T. Stillson $(1)$ and Zsofia Szendrei *(1) \\ Department of Entomology, Michigan State University, East Lansing, MI 48823, USA; stillson@msu.edu \\ * Correspondence: szendrei@msu.edu; Tel.: +1-517-974-8610
}

Received: 9 May 2020; Accepted: 29 June 2020; Published: 2 July 2020

\begin{abstract}
Aster yellows phytoplasma (Candidatus Phytoplasma asteris) is a multi-host plant pathogen and is transmitted by at least 24 leafhopper species. Pathogen management is complex and requires a thorough understanding of vector dynamics. In the American Midwest, aster yellows is of great concern for vegetable farmers who focus on controlling one vector, Macrosteles quadrilineatus - the aster leafhopper. However, vegetable-associated leafhopper communities can be diverse. To investigate whether additional species are important aster yellows vectors, we surveyed leafhopper communities at commercial celery and carrot farms in Michigan from 2018 to 2019 and conducted real-time PCR to determine infection status. Leafhoppers were collected within crop fields and field edges and identified with DNA barcoding. Overall, we collected 5049 leafhoppers, with the most abundant species being M. quadrilineatus (57\%) and Empoasca fabae-the potato leafhopper (23\%). Our results revealed the most abundant aster yellows vector in Michigan in both crops is M. quadrilineatus, but we also found that $E$. fabae may be a potential vector for this pathogen. While several taxa reside in and near these crops, we did not find strong evidence that they contribute to phytoplasma infection. These findings indicate that $M$. quadrilineatus should be the primary target for controlling this pathogen.
\end{abstract}

Keywords: Cicadellidae; insect vector; pest management; plant disease; phytoplasma

\section{Introduction}

Aster yellows phytoplasma (Candidatus Phytoplasma asteris) is an insect-vectored plant pathogen [1] which causes a variety of symptoms including yellowing, virescence, phyllody, witch's broom, and ultimately premature death [2]. Even when infected crops reach harvest, they are often unmarketable [1,3]. Aster yellows has been reported to reduce yields by $10 \%$ [4] and is one of the most widespread phytoplasmas, affecting 14 vegetable crops across various plant families [5-7]. It is vectored by at least 24 leafhoppers [8], which must acquire the phytoplasma from the environment by feeding on infected plants [1], since phytoplasmas are rarely transovarial [1,9]. Not all leafhoppers can transmit aster yellows, which may be associated with a narrow diet breadth, where the leafhoppers do not feed on the infected plant or do not feed on the phloem of the infected plant [7]. If a leafhopper feeds on an infected plant, the phytoplasma must successfully migrate to the salivary glands before transmission is possible $[10,11]$. Polyphagous leafhoppers can acquire phytoplasma from crops or weedy host plants and then spread it among susceptible crop fields or between the field and field edge [7].

Movement of phytoplasmas in agroecosystems is primarily facilitated by polyphagous leafhoppers feeding locally on infected host plants [1], and seasonal migrations of some leafhopper species from overwintering to summer habitats [12-14]. In North America, the main vector of aster yellows phytoplasma is the migratory Macrosteles quadrilineatus (Forbes) - the aster leafhopper (Hemiptera: Cicadellidae), a polyphagous species with over 300 host plants [15], and a broad geographic distribution [12] Macrosteles quadrilineatus may move between different crops, between fields, and into 
field edges to feed on grasses and weeds [16]. This movement among various host plants can increase the chances of other leafhopper vectors acquiring aster yellows [1,17]. Currently, M. quadrilineatus is the focus for controlling aster yellows phytoplasma for vegetable farmers in the Midwest, USA. However, agroecosystems can have diverse leafhopper communities. These leafhopper vectors may then create disease reservoirs in the field edge, especially in perennial weeds that can be a source of infection every year $[1,18,19]$. The identity and vector status of these other leafhopper taxa is understudied and may be important for developing sustainable management methods for aster yellows.

To investigate whether additional leafhopper species are important aster yellows vectors, we collected leafhoppers from commercial celery and carrot farms in Michigan during the 2018 and 2019 growing seasons. We collected leafhoppers from the crops and the field edges using sweep nets, identified the leafhoppers to the lowest taxonomic level possible using morphological identifications and DNA barcoding, conducted molecular diagnostics to determine whether they contained phytoplasma, and compared leafhopper species abundances in the different crops and locations. In order to identify leafhoppers and to detect aster yellows phytoplasma, we used established molecular tools. We identified the collected leafhoppers using, morphological features, existing information on their geographic distribution and DNA barcoding due to its widespread use, ease, and accuracy [20]. We relied on the growing databases of DNA sequences from identified species [21] that improve insect identification, especially in the case of taxa where taxonomic experts are lacking. Additionally, real-time PCR was used to detect phytoplasma infected leafhoppers. In recent years, real-time PCR has become an established and powerful tool for detecting phytoplasmas, as they cannot be grown in pure culture [22]. Real-time PCR has high sensitivity and is able to detect phytoplasma concentrations down to a single cell. It is performed in a single reaction vessel, making this an efficient and useful tool in phytoplasmas detection [22,23].

\section{Materials and Methods}

\subsection{Study System}

Leafhoppers were collected using sweep nets $(38 \mathrm{~cm}$ diameter aerial net) from mid-May through early August in the 2018 and 2019 growing seasons. All farms surveyed (Figure 1) were large-scale commercial operations, managed with synthetic pesticides. Sweep net samples were taken between 11:00 and 14:00 on clear days when insecticides had not been recently applied.
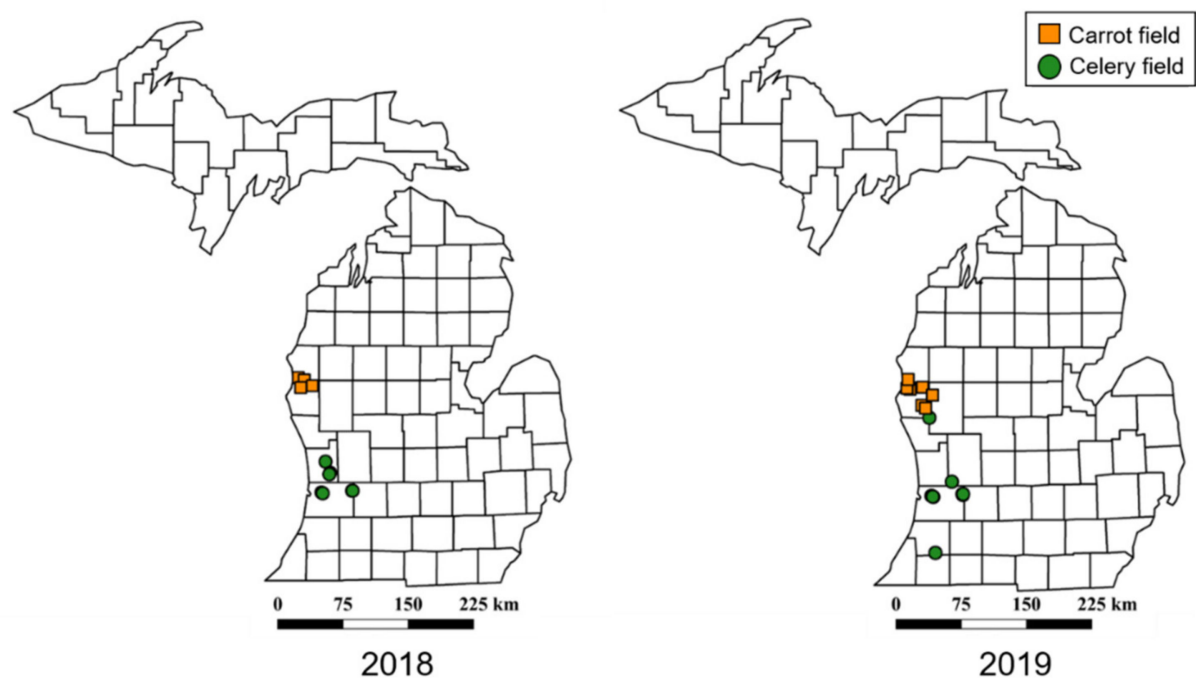

Figure 1. Map of collections sites from Michigan, USA. Symbols indicate locations of celery and carrot fields where leafhoppers were collected in 2018 and 2019. Leafhoppers were collected using sweep nets and transported to the laboratory for identification and to determine phytoplasma infectivity. 
In 2018, leafhoppers were collected three times from the field edge (26 June, 10 July, and 1 August) from one celery farm and weekly from inside seven celery and five carrot fields ( $n=36$ collections). In 2019, collections from both within the fields and from the edges were conducted weekly at ten celery and seven carrot farms ( $n=226$ collections). A minimum of 100 sweeps from inside the crop fields were taken from randomly chosen sites, approximately $>10 \mathrm{~m}$ into the field, away from the field edge. The 'field edge' consisted of naturally occurring vegetation around crop fields, along driveways, or along wooded edges (Figure 2A,B). In both years, sweeps were taken within randomly selected $5 \mathrm{~m}$ sections of the field edge; the total number of sweeps varied by field edge due to the variability in the amount of vegetation available for sweeping (200-500 sweeps/field). After collection, all leafhoppers were transported in a cooler from the field to the laboratory, where they were stored at $-20^{\circ} \mathrm{C}$.
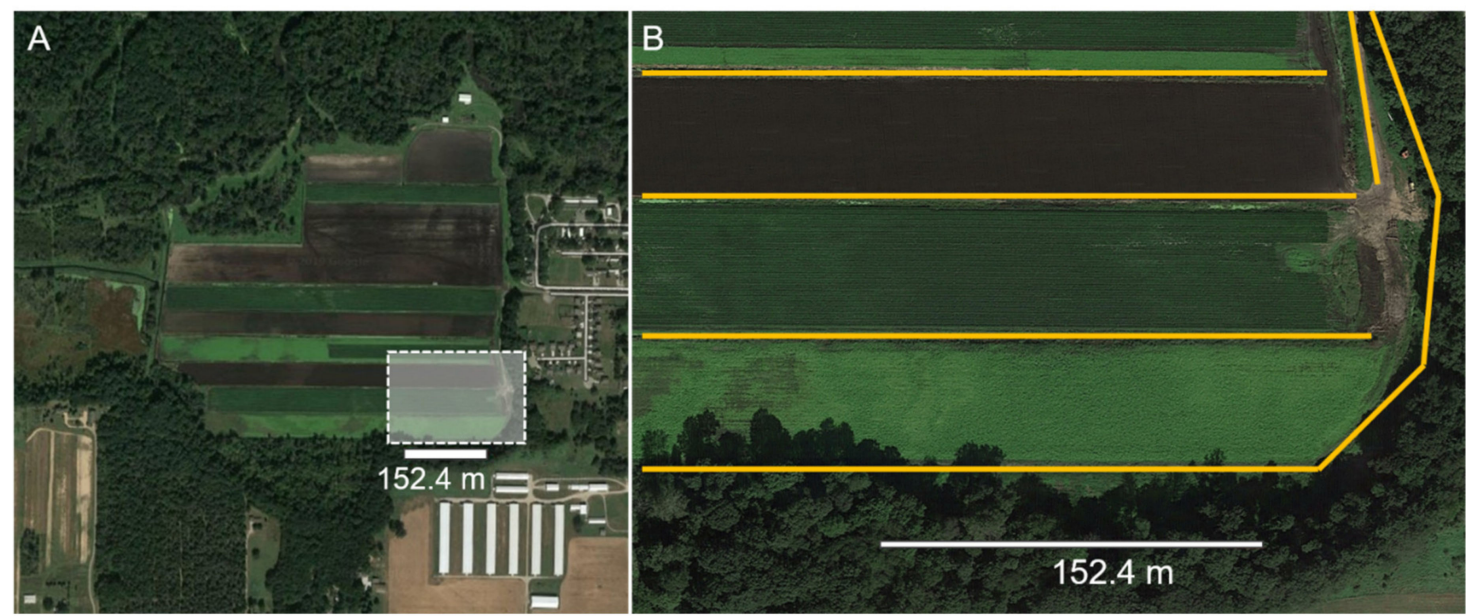

Figure 2. Leafhoppers were collected in celery and carrot field edges in Michigan in 2018 and 2019. (A) Aerial view of a celery field with boxed area magnified in B. (B) The surveyed field edge types are indicated by the yellow lines, consisting of vegetation between adjacent crop fields and edges between fields and non-agricultural vegetation, including weedy herbaceous plants growing along roads or paths adjacent to fields, or plants naturally growing along wooded edges.

\subsection{Leafhopper Identification}

In the laboratory, leafhoppers were sorted into several groups upon arrival from the field: M. quadrilineatus, Empoasca fabae (Harris) — the potato leafhopper, and other leafhoppers which were grouped based on morphological similarities. Macrosteles quadrilineatus and E. fabae were sight identified and were placed into homogenization tubes for DNA extraction. All M. quadrilineatus $(n=2883)$ DNA was extracted following Demeuse et al. [22]; modifications to this protocol included individually extracting DNA from each leafhopper and eluting DNA in $50 \mu \mathrm{L}$ elution buffer (Qiagen, Valencia, CA, USA).

For all of the non-M. quadrilineatus leafhoppers, we used a modified Dellaporta DNA extraction [24]. This protocol does not utilize a spin column and thus DNA is preserved in better condition for sequencing compared to the protocol described in Demeuse et al. [22] that uses a spin column potentially leading to DNA fragmentation. Leafhoppers $(n=2166)$ were placed individually in $2 \mathrm{~mL}$ homogenization tubes (Sarstedt, Nümbrecht, Germany), along with 3 homogenization beads (2.3 mm diameter, zirconia/silica; BioSpec Products, Bartlesville, OK, USA), and $400 \mu \mathrm{L}$ Dellaporta buffer (1 mL of $100 \mathrm{mM}$ Tris, pH 8.0, $1 \mathrm{~mL}$ of $500 \mathrm{mM}$ EDTA, $1.25 \mathrm{~mL} 500 \mathrm{mM} \mathrm{NaCl}, 10 \mu \mathrm{L} \beta$-mercaptoethanol and $6.75 \mathrm{~mL}$ of ultrapure water). Leafhoppers were homogenized for $10 \mathrm{~s}$ at $4.0 \mathrm{~m} / \mathrm{s}$ (FastPrep-24, MP Biomedicals, Irvine, CA, USA). Afterwards, $52.8 \mu \mathrm{L} 10 \%$ SDS was added, samples were vortexed then incubated at $65^{\circ} \mathrm{C}$ for $10 \mathrm{~min}$. After incubation, $128 \mu \mathrm{L} 5 \mathrm{M}$ potassium acetate was added. Samples were vortexed then centrifuged for $10 \mathrm{~min}$ at 15,000 rcf. Supernatant was removed and placed in a clean $1.7 \mathrm{~mL}$ centrifuge tube. Afterwards, $240 \mu \mathrm{L}$ cold isopropanol was added to the supernatant and the samples were incubated 
at room temperature for $5 \mathrm{~min}$. Samples were mixed by gentle inversion. Samples were placed in a $-20{ }^{\circ} \mathrm{C}$ freezer for $1 \mathrm{~h}$ and then centrifuged in a $4{ }^{\circ} \mathrm{C}$ refrigerated centrifuge (Centrifuge $5810 \mathrm{R}$, Eppendorf, Hamburg, Germany) for $20 \mathrm{~min}$ at 15,200 rcf. Supernatant was removed and $800 \mu \mathrm{L} 70 \%$ ethanol was added to the pelleted DNA. Samples were again mixed by gentle inversion and then placed back in the refrigerated centrifuge for $10 \mathrm{~min}$ at 15,200 rcf. The supernatant was removed, and pellets allowed to air dry. Pellets were suspended in $50 \mu \mathrm{L}$ elution buffer (Qiagen).

We used conventional PCR to amplify the cytochrome c oxidase subunit I (COI) gene using the Ron and Nancy primer set (Thermo Fisher Scientific, Waltham, MA, USA) [25] from 1 to 15 leafhoppers per morphotype based on the availability of leafhoppers per morphotype. We then cleaned the PCR product with QIAquick PCR Purification Kit (Qiagen) and submitted the DNA to Michigan State University's Research Technology Support Facility (RTSF) for Sanger sequencing. The sequences were compared to the National Center for Biotechnology Information genomic database (NCBI), and the leafhoppers were identified based on sequence match. The top result was accepted as a positive identification when the query sequence had a $95-100 \%$ sequence match, if it morphologically matched the collected leafhopper, and if the species' known geographic distribution overlapped with Michigan. In cases where the top result was rejected, we searched through the list of $>80 \%$ sequence matches for taxa that were acceptable based on morphology and geographic distribution. We identified morphotypes to the genus level (i.e., Agallia sp.), if the subset of sequenced leafhoppers from the same morphotype group were identified as different species, suggesting that multiple species make up that morphotype. For identifying leafhoppers based on morphology, we used previously identified leafhoppers from the Albert J. Cook Arthropod Research Collection at Michigan State University and Bug Guide [26]. For three morphotype groups (Athysanus argentarius (Metcalf), Idiocerus raphus (Freytag), and Norvellina sp.), only a few leafhoppers were collected, and these consistently provided poor sequencing results. These leafhoppers were only identified based on morphological comparisons to leafhoppers found in the Albert J. Cook Arthropod Research Collection. Morphological features used for comparisons included body and wing coloration, markings on the head, size, and wing venation. Some morphotype groups could not be identified, and thus they were recorded as unidentified.

For those leafhoppers that were identified to the species level, individuals were counted and recorded by species. Unidentified morphotypes were grouped as unknown Cicadellidae and their numbers recorded. Leafhoppers were divided into commonly collected ( $\geq 50$ leafhoppers collected) or rare ( $<50$ leafhoppers collected) taxa. For future reference, one adult specimen of each morphological group was pinned, or one nymph was preserved in $70 \%$ ethanol. Voucher specimens for all identified leafhoppers were stored in the Albert J. Cook Arthropod Research Collection, Michigan State University (voucher number: 2019-09), except for Erythroneura sp., morphotype 15, and 16 (Figure S1-S3). Sequences used for identification were deposited on NCBI GenBank with accession numbers MT643826-MT643893 (Table S1).

\subsection{Detection of Phytoplasma}

All leafhoppers were evaluated for the presence of aster yellows phytoplasma with a real-time PCR TaqMan assay [22], using universal phytoplasma primers and probe [23] (Thermo Fisher Scientific). Leafhoppers were tested in duplicate, and if one of the replicates tested positive for the presence of phytoplasma (cycle threshold $\left(C_{t}\right)$ value $\leq 40$ ) and the other was negative, the leafhopper was retested. For $M$. quadrilineatus, we used a $C_{\mathrm{t}}$ value $<32$ to determine positives, as established for our regular diagnostic work for farmers [22]. All non-M. quadrilineatus with $C_{t}$ values $\leq 40$, were also tested with conventional PCR using P3/P7 universal phytoplasma primers [27] to verify the presence of phytoplasma. The PCR products were run on a $1 \%$ agarose gel precast with GelRed (Biotium, Fremont, CA, USA) for $1 \mathrm{~h}$ at $90 \mathrm{~V}$. Bands were visualized with a UV transilluminator (Bioolympics, Thousand Oaks, CA, USA). In addition, we searched the literature to determine which of the collected leafhoppers are known vectors for aster yellows phytoplasma or other phytoplasmas, or if there are congeners that are phytoplasma vectors. Vector status for leafhoppers found through the 
literature search was determined through transmission studies where leafhoppers inoculated healthy test plants or inoculated sucrose solutions. We then compared the collected leafhopper species to this list of documented vectors.

\subsection{Data Analysis}

To identify which leafhopper species may be feeding on the crops, or moving between the crops and field edge, we determined whether there were differences in leafhopper species abundance between species found in both locations and crops. We used a generalized linear model, where crop type and field location were fixed factors. Differences among means of tested factors were determined with post-hoc pairwise comparison (Tukey's HSD: $\alpha=0.05$; function = 'emmeans', package = 'emmeans') [28]. The total number of leafhoppers per 100 sweeps was used for each of the most abundant leafhopper species (genera or species $\geq 50$ leafhoppers collected). Leafhoppers per 100 sweeps was used to standardize leafhopper densities across collections with different numbers of sweeps. We performed separate statistical analyses for celery and carrot.

To determine whether there were differences in the number of infected M. quadrilineatus between the crop and field edge, we used a generalized linear model, where field location (inside or outside field) was used as a fixed factor. Differences among means of tested factors was again determined with post-hoc pairwise comparison (Tukey's HSD: $\alpha=0.05$ ). In addition, this was also performed using crop (carrot or celery) as a fixed factor. All statistical analyses were conducted in R v.3.6.0 [29]. Data used in statistical analyses is provided in Table S2.

\subsection{Phylogenetic Analysis}

Gene sequences (COI) were aligned using MAFFT version 7.450 [30] with the default parameters. Maximum-likelihood phylogenetic trees were generated with RAxML version 8.2.10 [31] using a GTR+Gamma model on the CIPRES Science Gateway [32]. Node support values were calculated using rapid bootstrapping with 500 replicates.

\section{Results}

In total, we collected 5049 leafhoppers from celery and carrot fields and their field edges combined during the 2018 and 2019 growing seasons. We identified 25 leafhopper taxa with 14 identified to the species level, 11 identified to the genus level, and 16 morphotypes identified to family level (Cicadellidae; Figure 3A-Z, Table 1). Out of the common taxa that represented 94\% of collected leafhoppers, eight were identified (five were identified to the species level and three to the genus level; Table 1). The most abundant species were M. quadrilineatus (57\%) and E. fabae (23\%).

\subsection{Carrot Leafhopper Collections}

We collected 2995 leafhoppers from carrot farms in 2018 and 2019, with 1932 leafhoppers (65\%) collected from within carrot fields and 1063 (35\%) from the field edges. A total of 23 taxa were identified with 13 identified to the species level and 10 identified to the genus level. The most abundant leafhopper taxa were M. quadrilineatus (62\%), E. fabae (16\%), Doratura stylata (Boheman) (6\%), and Latalus sp. (5\%) ( $\geq 50$ individuals collected for each). Leafhoppers found only in carrots included Commellus sp., Cuerna sp., Diplocolenus subg. verdanus, Doratura stylata, Elymana inornata (Van Duzee), Endria inimica (Say), and Graphocephala hieroglyphica (Say). When comparing the abundances of the eight most abundant leafhopper taxa within and around carrot fields, M. quadrilineatus had 1.75-fold greater abundance within the carrot fields than in the field edge ( $p$-value $\leq 0.01)$, E. fabae had 4.20-fold greater abundance within the field ( $p$-value $=0.99$; Figure 4A), as did Psammotettix lividellus (Zetterstedt) with 1.44-fold greater abundance in the field ( $p$-value $=0.99)$ than in the field edge. Conversely, Latalus sp., Balclutha sp., and Draeculacephala sp. had greater abundances within the field edges than in the carrot fields, with 3.00- $(p$-value $=0.97), 2.00$ - $(p$-value $=0.99)$, and 1.94 - $(p$-value $=0.78)$ fold more leafhoppers 
collected respectively. Two other species-Aphrodes bicinctus (Schrank) and D. stylata-were only found in the carrot field edge (Figure $4 \mathrm{~B}, \mathrm{C}$ ).

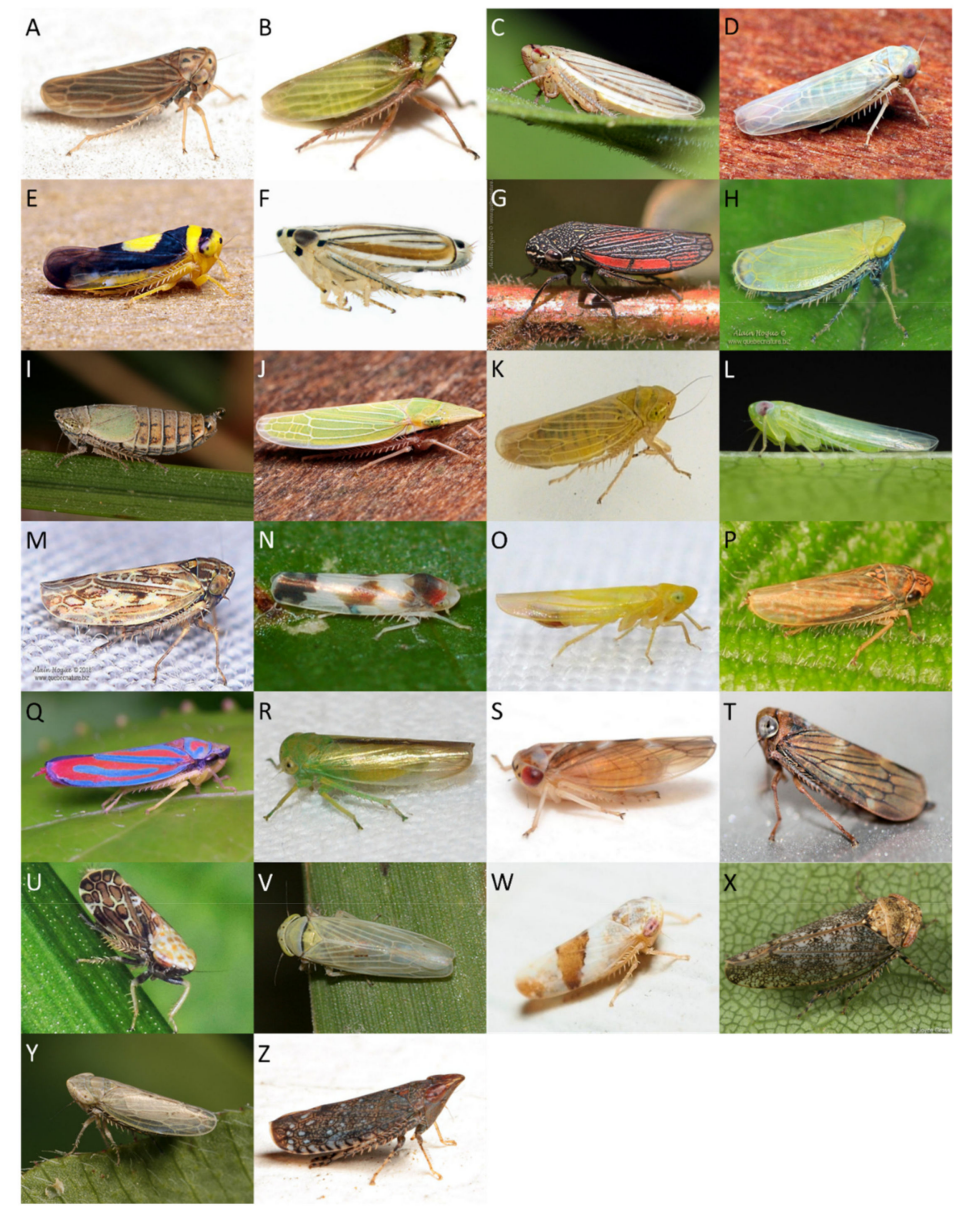

Figure 3. Leafhoppers collected from Michigan, USA, celery and carrot farms in the period 2018-2019. (A) Agallia sp., (B) Aphrodes bicinctus, (C) Athysanus argentarius, (D) Balclutha sp., (E) Colladonus clitellarius, (F) Commellus sp., (G) Cuerna sp. ${ }^{*},(\mathbf{H})$ Diplocolenus subg. verdanus, (I) Doratura stylata, (J) Draeculacephala sp., (K) Elymana inornata, (L) Empoasca fabae, (M) Endria inimica, (N) Erythroneura sp., (O) Forcipata loca, (P) Graphocephala hieroglyphica *, (Q) Graphocephala sp., (R) Idiocerus raphus, (S) Idiocerus sp., (T) Jikradia olitoria, (U) Latalus sp., (V) Macrosteles quadrilineatus, (W) Norvellina sp., (X) Paraphlepsius sp., (Y) Psammotettix lividellus, and (Z) Scaphytopius sp. Note: * indicates that only nymphs were collected; all other leafhoppers were collected as adults or as both adults and nymphs. See acknowledgements for photo credits.

We collected 2054 leafhoppers from 2018 and 2019 from celery farms, with 701 leafhoppers (34\% of the total) collected from within the celery fields and 1353 (66\%) from the field edge. A total of 18 taxa were identified, with 9 identified to the species level and 9 identified to the genus level. Macrosteles quadrilineatus (50\%), E. fabae (32\%), and P. lividellus (9\%) were the most abundant leafhopper taxa ( $\geq 50$ individuals collected of each). Erythroneura sp. was only found in celery fields but not in field edges. When comparing the abundances of the eight most abundant leafhopper taxa within and outside celery fields, they were all predominantly found in the field edge. Macrosteles quadrilineatus was 1.65-fold more abundant in celery field edges than within the field ( $p$-value $\leq 0.01$ ), similarly, E. fabae was 2.23 -fold more abundant in field edges than within celery fields ( $p$-value $=0.03$; Figure $4 \mathrm{~A})$. Psammotettix lividellus and Balclutha sp. were both found primarily outside celery fields with 1.13 - $(p$-value $=0.97)$ and 1.21- $(p$-value $=0.97)$ fold greater abundances in the edge respectively than in the celery field. 
Three other taxa-Latalus sp., A. bicinctus, and Draeculacephala sp.-were found only in the field edge (Figure 4D,E). Doratura stylata was absent from celery fields and edge collections.

Table 1. Leafhoppers collected from commercial celery and carrot farms in Michigan, USA, from 2018 to 2019. Field edges were defined as areas bordering the crop field or between adjacent fields where crops were not growing. Fractions indicate the number of individuals that generated cycle thresholds $\left(C_{t} \leq 40\right)$ in a real-time PCR with universal phytoplasma primers [23] out of the total number of individuals collected.

\begin{tabular}{|c|c|c|c|c|c|c|c|}
\hline Genera/Species & $\begin{array}{c}\text { Celery } \\
\text { Field }\end{array}$ & $\begin{array}{c}\text { Celery } \\
\text { Edge }\end{array}$ & $\begin{array}{c}\text { Carrot } \\
\text { Field }\end{array}$ & $\begin{array}{c}\text { Carrot } \\
\text { Edge }\end{array}$ & $\begin{array}{c}2018 \\
\text { Total }\end{array}$ & $\begin{array}{l}2019 \\
\text { Total }\end{array}$ & $\begin{array}{l}C_{\mathrm{t}} \text { Value } \\
\text { or Range }\end{array}$ \\
\hline Agallia sp. & 2 & 7 & 10 & 24 & 5 & 38 & - \\
\hline Aphrodes bicinctus ${ }^{\dagger}$ & 0 & 49 & 0 & 29 & 9 & 69 & - \\
\hline Athysanus argentarius & 0 & 2 & 0 & 6 & 0 & 8 & - \\
\hline Balclutha sp. ${ }^{\dagger}$ & 1 & 29 & $1 / 2$ & 23 & $1 / 21$ & 34 & 36.97 \\
\hline Colladonus clitellarius & 1 & 0 & 0 & 2 & 1 & 2 & - \\
\hline Commellus sp. & 0 & 0 & 0 & 2 & 0 & 2 & - \\
\hline Cuerna sp. & 0 & 0 & 1 & 2 & 0 & 3 & - \\
\hline Diplocolenus subg. verdanus & 0 & 0 & 0 & 32 & 0 & 32 & - \\
\hline Doratura stylata ${ }^{+}$ & 0 & 0 & 0 & $1 / 191$ & 0 & $1 / 191$ & 34.93 \\
\hline Draeculacephala sp. ${ }^{+}$ & 0 & $1 / 23$ & 3 & 45 & 1 & $1 / 70$ & 39.90 \\
\hline Elymana inornata & 0 & 0 & 0 & 2 & 0 & 2 & - \\
\hline Empoasca fabae ${ }^{+}$ & $6 / 235$ & $6 / 418$ & 409 & 75 & $11 / 304$ & $5 / 833$ & $25.20-40.00$ \\
\hline Endria inimica & 0 & 0 & 0 & 6 & 0 & 6 & - \\
\hline Erythroneura sp. & 1 & 0 & 0 & 0 & 1 & 0 & - \\
\hline Forcipata loca & 0 & 8 & 0 & 1 & 0 & 9 & - \\
\hline Graphocephala hieroglyphica & 0 & 0 & 41 & 5 & 0 & 46 & - \\
\hline Graphocephala sp. & 0 & $1 / 1$ & 27 & 1 & $1 / 28$ & 1 & 40.00 \\
\hline Idiocerus raphus & 3 & 1 & 0 & 1 & 3 & 2 & - \\
\hline Idiocerus sp. & 0 & $1 / 11$ & 0 & 0 & $1 / 10$ & 1 & 36.51 \\
\hline Jikradia olitoria & 0 & 6 & 0 & 2 & 0 & 8 & - \\
\hline Latalus sp. ${ }^{+}$ & 0 & 2 & 2 & $4 / 135$ & 0 & $4 / 139$ & $35.39-37.03$ \\
\hline Macrosteles quadrilineatus ${ }^{\dagger}$ & $1 / 447$ & $3 / 582$ & $7 / 1423$ & $1 / 431$ & $3 / 707$ & $9 / 2176$ & $17.56-31.73$ \\
\hline Norvellina sp. & 1 & 1 & 0 & 0 & 1 & 1 & - \\
\hline Paraphlepsius sp. & 0 & 11 & 5 & 2 & 2 & 16 & - \\
\hline Psammotettix lividellus $^{+}$ & 8 & $1 / 187$ & 1 & 18 & 0 & $1 / 214$ & 36.93 \\
\hline Scaphytopius sp. & 2 & 10 & $1 / 2$ & 4 & $1 / 4$ & 14 & 39.30 \\
\hline Unknown Cicadellidae & 0 & 5 & 6 & 24 & 4 & 31 & - \\
\hline Total leafhoppers collected & $7 / 701$ & $13 / 1353$ & 9/1932 & $6 / 1063$ & $18 / 1101$ & $21 / 3948$ & \\
\hline
\end{tabular}

${ }^{+}$Indicates the eight most abundant leafhopper taxa ( $\geq 50$ individuals collected of each).

\subsection{Celery Leafhopper Collections}

\subsection{Phytoplasma Infectivity}

Across the two study years, $12 \mathrm{M}$. quadrilineatus tested positive for aster yellows using the $C_{\mathrm{t}}$ value threshold of 32 typically used in our detection assay [22]. Twenty-seven individuals from nine other taxa had $C_{\mathrm{t}}$ values between 25.2 and 40: 16 E. fabae, 4 Latalus sp., 1 Balclutha sp., 1 Draeculacephala sp., 1 D. stylata, 1 Graphocephala sp., 1 Idiocerus sp., 1 P. lividellus, and 1 Scaphytopius sp. (Table 1). One E. fabae tested positive for aster yellows phytoplasma using P3/P7 primers, while all the other leafhoppers were negative for aster yellows with this primer set.

In addition, we found three known aster yellows phytoplasma vectors in our collections including A. bicinctus, Athysanus argentarius, and E. inimica but none of these produced $C_{\mathrm{t}}$ values $\leq 40$. Of the leafhoppers that were identified to genus, Agallia sp., Paraphlepsius sp., and Scaphytopius sp. may potentially be vectors since there are aster yellows vectors in these genera. Of those we identified to the species level, Colladonus clitellarius (Say), E. inornata, and G. hieroglyphica while not known to transmit aster yellows, other species in their genera are aster yellows vectors ( Table 2; Table 3). 

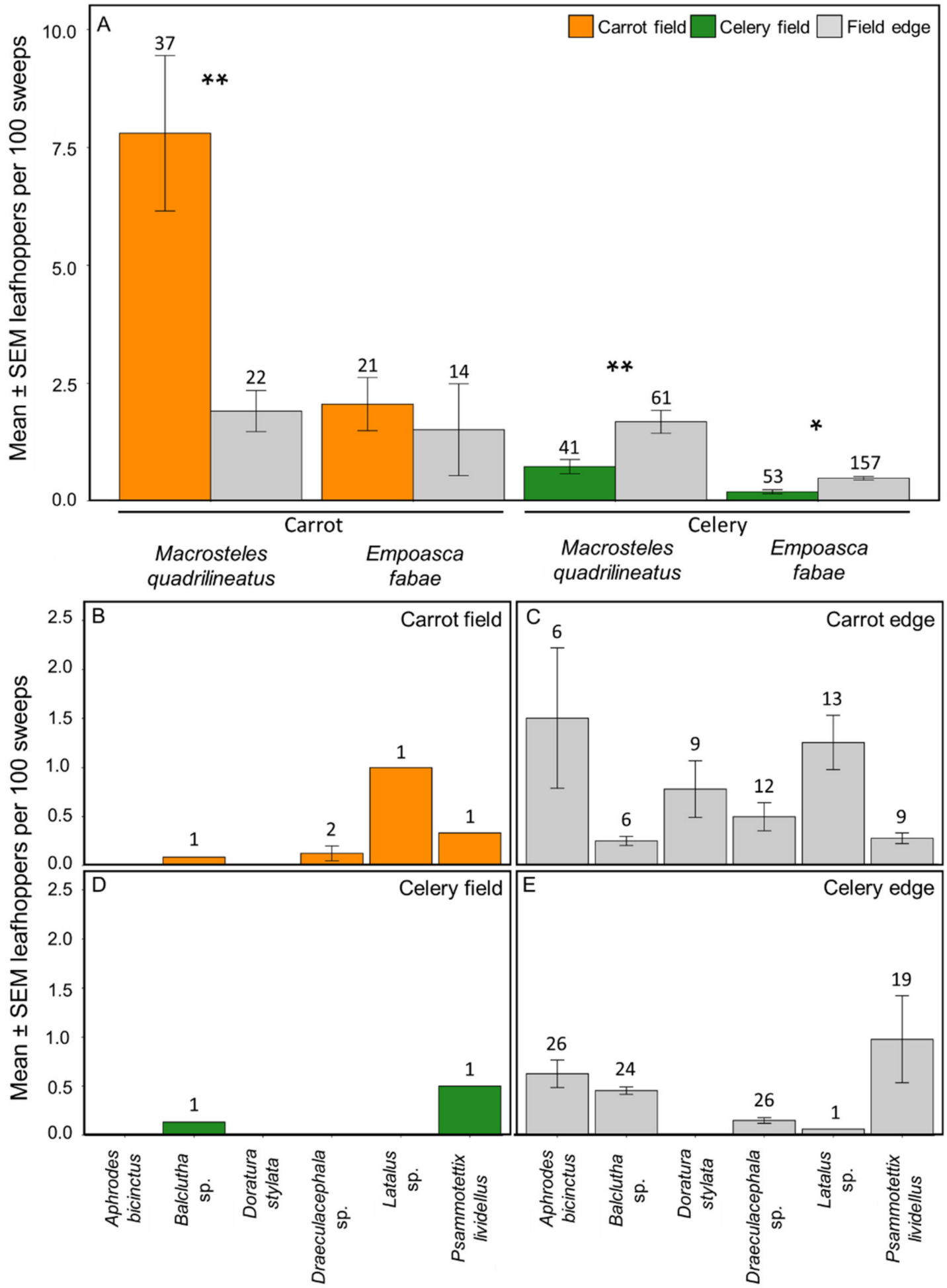

\section{Leafhopper species}

Figure 4. Mean \pm SEM leafhoppers per 100 sweeps of the eight most abundant leafhopper taxa ( $\geq 50$ individuals collected) from commercial carrot and celery fields and field edges in Michigan in 2018 and 2019. Macrosteles quadrilineatus and Empoasca fabae were the most commonly collected species (A). Six other abundant leafhopper taxa ( $\geq 50$ individuals collected of each) were represented in our samples from carrot fields (B), carrot field edges (C), celery fields (D), and celery field edges (E). Numbers above bars indicate the number of collections for each taxa and location. Asterisks indicate statistically significant differences between field and edge collections for each taxa (Tukey's HSD; * $p$-value $\leq 0.05$, ** $p$-value $\leq 0.01)$. 
Table 2. Known leafhopper vectors of aster yellows phytoplasma or other phytoplasmas for the leafhoppers collected in this study. Phytoplasma abbreviations are AWB = alfalfa witches broom, AshY = ash yellows, $\mathrm{AYp}=$ aster yellows, $\mathrm{Cp}=$ clover phyllody, $\mathrm{CYE}=$ clover yellow edge, East $\mathrm{X}=$ Eastern $\mathrm{X}$, EAYp = European aster yellows, GFD = Grape flavescence doree, NAGVY = North American grapevine yellows IIIB, Sp = stolbur, and SGP = strawberry green petal. Diplocolenus subg. verdanus, Doratura stylata, Forcipata loca (DeLong \& Caldwell), and Idiocerus raphus were omitted as there is no record of whether they or their congeners vector phytoplasmas.

\begin{tabular}{|c|c|c|c|c|c|}
\hline Species & $\begin{array}{l}\text { Vectors } \\
\text { AYp }\end{array}$ & $\begin{array}{l}\text { Vectors Other } \\
\text { Phytoplasmas }\end{array}$ & $\begin{array}{l}\text { Congener } \\
\text { Vectors AYp }\end{array}$ & $\begin{array}{c}\text { Congener Vectors Other } \\
\text { Phytoplasmas }\end{array}$ & References \\
\hline Aphrodes bicinctus & Yes & $\begin{array}{c}\text { Cp, CYE, EAYp, } \\
\text { SGP, Sp }\end{array}$ & - & A. albifrons & {$[8,33,34]$} \\
\hline Athysanus argentarius & Yes & - & - & - & [35] \\
\hline Colladonus clitellarius & -+ & AshY, EastX & $\begin{array}{l}\text { C. geminatus, } C \text {. } \\
\text { montanus } \\
\text { montanus }\end{array}$ & $\begin{array}{c}\text { C. geminatus,C. montanus } \\
\text { montanus }\end{array}$ & {$[8,36-41]$} \\
\hline Elymana inornata & - & - & E. sulphurella & E. virescens & [42-44] \\
\hline Empoasca fabae & - & - & - & E. decipiens, E. papayae & [45-47] \\
\hline Endria inimica & Yes & - & - & - & [48] \\
\hline $\begin{array}{l}\text { Graphocephala } \\
\text { hieroglyphica }\end{array}$ & - & AWB & G. severini & G. confluens, G. severini & {$[8,49,50]$} \\
\hline Jikradia olitoria & - & NAGVY & - & - & [51] \\
\hline Macrosteles quadrilineatus & Yes & Cp, EAYp, Sp & M. sexnotatus & $\begin{array}{c}\text { M. cirstata, M. laevis, } \\
\text { M. quadripunctulatus, } \\
\text { M. sexnotatus, M. striifrons, } \\
\text { M. viridigriseus }\end{array}$ & {$[19,33,52-65]$} \\
\hline Psammotettix lividellus & - & GFD & - & P. cephalotes, $P$. striatus & {$[8,18,66]$} \\
\hline
\end{tabular}

${ }^{+}$Indicates that no data is available about whether the species or congeners can vector AYp or other phytoplasmas.

Table 3. Known leafhopper vectors of aster yellows phytoplasma or other phytoplasmas for the leafhoppers collected in this study. Commellus sp., Draeculacephala sp., and Erythroneura sp. were omitted as there is no record of whether species in these genera vector phytoplasmas.

\begin{tabular}{cccc}
\hline Genus & Vectors AYp & $\begin{array}{c}\text { Vectors Other } \\
\text { Phytoplasmas }\end{array}$ & References \\
\hline Agallia sp. & A. constricta & - & {$[67,68]$} \\
Balclutha sp. & $-{ }^{+}$ & B. punctata & {$[69]$} \\
Cuerna sp. & - & C. septentrionalis & {$[50]$} \\
Latalus sp. & - & Latalus sp. & {$[70]$} \\
Norvellina sp. & - & N. seminuda & {$[51]$} \\
Paraphlepsius sp. & P. apertinus, P. irroratus & P. irroratus & {$[8,36,68,71]$} \\
Scaphytopius sp. & S. acutus acutus, S. acutus delongi & $\begin{array}{c}\text { S. acutus acutus, S. acutus } \\
\text { delongi, S. magdalensis }\end{array}$ & {$[8,36,40,72-77]$} \\
\hline
\end{tabular}

${ }^{\dagger}$ Indicates that no data is available about whether the genera can vector AYp or other phytoplasmas.

There was no difference in the number of infected M. quadrilineatus between crops ( $p$-value $=0.61$ ) or between the field and the field edge $(p$-value $=0.67)$.

\subsection{Phylogenetic Analysis}

According to the generated maximum-likelihood phylogeny (Figure S4), the COI-identified leafhoppers were placed with the same taxa, except for five sequences found on the top of the tree (1 Cuerna sp., 2 E. fabae, and 2 Paraphlepsius spp.). These sequences did not fall into the appropriate groups possibly due to low quality sequencing. Additionally, from this analysis, we generated a sequence dissimilarity matrix listing the number of nucleotide differences and overall percent difference between all COI sequences (Table S3). When leafhopper sequences were observed within the same clade, there was less than $10 \%$ difference between the sequences, while they had 10-30\% differences between neighboring clades or branches. This provides evidence that our COI barcoding was effectively able to distinguish different leafhopper species. 


\section{Discussion}

Our leafhopper survey confirmed that M. quadrilineatus is the primary leafhopper vector of aster yellows phytoplasma in Michigan celery and carrot agroecosystems, which is consistent with findings from Ohio [12] and Wisconsin [78] carrot fields, and is the first study to confirm this in Midwestern celery fields. While other leafhopper species reside in and near these crops, we did not find strong evidence that they contribute to phytoplasma infections within these crops. Additionally, we determined that the leafhopper communities were different between the two agroecosystems with the field edges characterized by a greater diversity of species than the crop fields.

With aster yellows phytoplasma's wide host plant range [5], it is essential to identify its leafhopper vectors that may threaten crops. Our results indicated that across both celery and carrot cropping systems, M. quadrilineatus was the most abundant species, and although carrots overall had more diversity in leafhopper taxa, the edges of both crops were comparable in leafhopper abundance and composition. The known aster yellows phytoplasma vectors collected were A. bicinctus, A. argentarius, and E. inimica (only in carrot) which were all found in the field edge and are known to feed on grasses, cereals, and clover [35,42,79]. We also collected Scaphytopius sp. from both cropping systems and while they are likely to be Scaphytopius acutus (Say), a known vector of aster yellows [80], we did not find strong evidence that this leafhopper is vectoring phytoplasma $\left(C_{t}=39.3, n=1\right)$. Unlike some of the other leafhopper species in our collections, Scaphytopius sp. was found in both carrot and celery fields and field edges, indicating that it is likely to frequently move to new host plants. Doratura stylata and Latalus sp. had the lowest $C_{t}$ values $\left(C_{t}=34.93, n=1 ; C_{t}=35.39-37.03, n=4\right)$, besides $M$. quadrilineatus and E. fabae. While D. stylata has not been reported in the literature as a phytoplasma vector, Latalus sp. has been reported as a vector, but we were unable to verify the real-time PCR findings with conventional PCR and sequencing. High $C_{t}$ values can potentially result when non-vector leafhoppers feed on an infected plant and the phytoplasma is present in the digestive tract [81]. Because of this, the only way to confirm vector status is through transmission assays which involve feeding suspected vectors on phytoplasma infected plants to acquire the pathogen, and having them inoculate healthy plants or a sucrose solution $[48,80,82]$. If the disease is detected in the plant, after a latency period lasting up to a month, or in the sucrose solution after inoculation, then the leafhopper is a vector for the phytoplasma $[48,80,82]$. Nevertheless, real-time PCR is known to be more sensitive for aster yellows detection than conventional PCR [22]; thus, we cannot exclude the possibility that some of the leafhoppers with high $C_{t}$ values are in the early stages of infection.

We verified one E. fabae with conventional PCR and sequencing as containing aster yellows phytoplasma. Empoasca fabae has previously been detected with a strain of aster yellows, although the authors did not confirm vector status using bioassays [83]. Two other Empoasca spp. are known phytoplasma vectors: Empoasca papayae (Oman) vectors Papaya Bunchy Top associated with Candidatus Phytoplasma aurantifolia [45,47,84], and Empoasca decipiens (Paoli) vectors chrysanthemum yellows phytoplasma, which is closely related to aster yellows (Table 2) [46].

Although we hypothesized that field edges may be disease reservoirs and a source of infection for the crops, our findings indicate that the edge may not be the primary source of phytoplasma infection. Since more $M$. quadrilineatus were positive for aster yellows in samples collected from within crop fields, compared to field edges, this could indicate that aster yellows phytoplasma is brought into the field by migrating M. quadrilineatus that later move from the crop to the field edge [33,34]. In the field edge, infected M. quadrilineatus can infect plants which may become disease reservoirs and sources of aster yellows phytoplasma for other leafhoppers.

Based on our findings, M. quadrilineatus had higher abundance in carrot fields compared to celery which could be due to differences in the management of the two crops. For example, celery is transplanted in the spring, while carrots are direct seeded, and thus celery is available earlier in the season for M. quadrilineatus colonization than carrots. Carrots are grown in counties North of the celery producing area (Figure 1), accentuating the difference in developmental stages between the two crops. The management intensity of the two crops is also different with more frequent insecticide 
applications in celery compared to carrots (personal observation, Z. Szendrei). This is likely due to the direct damage to celery stems and leaves by annually occurring pests such as caterpillars and aphids and the relatively higher value of celery compared to carrots (\$19.5 million and \$14.5 million respectively in Michigan in 2018) [85].

Areas surrounding crop fields such as field edges can play an important role in the lifecycle of vectored pathogens not only for creating disease reservoirs but for managing vector populations using trap crops [86]. Differences in host plant preference could be used to attract M. quadrilineatus away from crops to trap crops planted in field edges. For trap crops to work effectively, we first need to identify plants that are more attractive to $M$. quadrilineatus compared to the vegetable crops [87]. By planting trap crops, we may be able to mostly contain the leafhoppers in the field edge, especially when crops are in their most susceptible developmental stages. It will also be important to screen for aster yellows-resistant hosts, from which phytoplasma cannot be acquired and transmitted to other plants. Since other leafhopper species are likely not as important in aster yellows transmission, focusing on M. quadrilineatus behavioral management could potentially be an effective and sustainable strategy to reduce aster yellows' economic impact. In addition, farmers may implement other control measures, such as mowing weedy field margins, thus reducing potential alternative hosts for both aster yellows and M. quadrilineatus. These management strategies can also be paired with diagnostics based support tools that inform growers about leafhopper infectivity [88]. By utilizing multiple methods for management, farmers will be able to better control aster yellows phytoplasma in a sustainable way.

\section{Conclusions}

Insect-vectored plant pathogens are challenging to manage with sustainable methods, especially when both the vector and pathogen have wide host ranges. Here, we made an important first step by confirming that $M$. quadrilineatus is an important vector of aster yellows and that E. fabae may potentially be another vector in celery and carrot agroecosystems. The next step will be to conduct transmission tests to determine whether E. fabae can vector aster yellows, as they are often abundant in aster yellows-susceptible crops-many of which also have M. quadrilineatus [89,90]. Both leafhoppers are found in the fields and field edges of celery and carrot fields, and if E. fabae can vector aster yellows, limiting where the leafhoppers can acquire the pathogen by using disease-resistant trap crops will minimize phytoplasma prevalence.

Supplementary Materials: The following are available online at http://www.mdpi.com/2075-4450/11/7/411/s1, Figure S1: Erythroneura sp. voucher specimen, Figure S2: Morphotype 15 voucher specimen, Figure S3: Morphotype 16 voucher specimen, Figure S4: Phylogenetic tree of leafhopper COI sequences, Table S1: Accession number data, Table S2: Data used in analyses, Table S3: Pairwise dissimilarity matrix.

Author Contributions: Conceptualization, P.T.S. and Z.S.; data curation, P.T.S. and Z.S.; formal analysis, P.T.S.; funding acquisition, Z.S.; investigation, P.T.S.; methodology, P.T.S. and Z.S.; project administration, Z.S.; resources, Z.S.; supervision, Z.S.; validation, P.T.S.; visualization, P.T.S.; writing_original draft, P.T.S.; writing-review and editing, P.T.S. and Z.S. All authors have read and agreed to the published version of the manuscript.

Funding: Financial support provided by the Michigan Celery Research Commission, the Michigan Carrot Committee, the Michigan Vegetable Council, Michigan State University's Project GREEEN grant program, and the MDARD Specialty Crops Block Grant.

Acknowledgments: We would like to thank Carolyn Malmstrom for providing feedback on the manuscript and Ellen Cole for helping to analyze the infected leafhoppers. We would also like to thank the celery and carrot growers who let us access their farms to collect leafhoppers and Mark Crossley, Benjamin Werling (MSU-Extension, West Michigan Vegetable Extension Educator), and the undergraduate technicians who assisted in data collection and specimen processing. Leafhopper photos were used with permission from David Cappaert (Figure 3C), Ken Childs (Figure 3A,D,E,J,Z), Peter Cristofono (Figure 3T), Charley Eiseman (Figure 3N), Judy Gallagher (Figure 3P), Joyce Gross (Figure 3X), Jon Hart (Figure 3Q,W), MJ Hatfield (Figure 3F), Alain Hogue (Figure 3G,H,M,U), Kyle Kittelberger (Figure 3B,O,S), Ilona Loser (Figure 3K,R), Tom Murray (Figure 3V), Claude Pilon (Figure 3I,Y), and John Schneider (Figure 3L).

Conflicts of Interest: The authors declare no conflict of interest. 


\section{References}

1. Weintraub, P.G.; Beanland, L. Insect vectors of phytoplasmas. Annu Rev. Entomol 2006, 51, 91-111. [CrossRef] [PubMed]

2. Dickinson, M.; Tuffen, M.; Hodgetts, J. The Phytoplasmas: An Introduction. In Phytoplasmas: Methods and protocols, 1st ed.; Dickinson, M., Hodgetts, J., Eds.; Humana: New York, NY, USA, 2013; pp. 1-14. [CrossRef]

3. Bertaccini, A.; Duduk, B. Phytoplasma and phytoplasma diseases: A review of recent research. Phytopathol. Mediterr. 2009, 48, 355-378. [CrossRef]

4. Kunkel, L.O. Cross protection between strains of yellows-type viruses. In Advances in Virus Research; Smith, K.M., Lauffer, M.A., Eds.; Academic Press: New York, NY, USA, 1955; Volume 3, pp. $251-273$. [CrossRef]

5. Kumari, S.; Nagendran, K.; Rai, A.B.; Singh, B.; Rao, G.P.; Bertaccini, A. Global status of phytoplasma diseases in vegetable crops. Front. Microbiol. 2019, 10, 1349. [CrossRef]

6. Lee, I.-M. "Candidatus Phytoplasma asteris", a novel phytoplasma taxon associated with aster yellows and related diseases. Int. J. Syst. Evol. Microbiol. 2004, 54, 1037-1048. [CrossRef] [PubMed]

7. Lee, I.-M.; Davis, R.E.; Gundersen-Rindal, D.E. Phytoplasma: Phytopathogenic mollicutes. Annu. Rev. Microbiol. 2000, 54, 221-255. [CrossRef]

8. Tsai, J.H. Vector transmission of mycoplasmal agents of plant diseases. In The Mycoplasmas; Barile, M.F., Razin, S., Tully, J.G., Whitcomb, R.F., Eds.; Academic Press: New York, NY, USA, 1979; Volume 3, pp. $265-307$.

9. Alma, A.; Bosco, D.; Danielli, A.; Bertaccini, A.; Vibio, M.; Arzone, A. Identification of phytoplasmas in eggs, nymphs and adults of Scaphoideus titanus Ball reared on healthy plants. Insect Mol. Biol. 1997, 6, 115-121. [CrossRef]

10. Wayadande, A.C.; Baker, G.R.; Fletcher, J. Comparative ultrastructure of the salivary glands of two phytopathogen vectors, the beet leafhopper, Circulifer tenellus (Baker), and the corn leafhopper, Dalbulus maidis Delong and Wolcott (Homoptera: Cicadellidae). Int. J. Insect Morphol. Embryol. 1997, 26, 113-120. [CrossRef]

11. Nakajima, S.; Nishimura, N.; Jung, H.; Kakizawa, S.; Fujisawa, I.; Nanba, S.; Tsuchizaki, T. Movement of onion yellows phytoplasma and Cryptotaenia japonica witches' broom phytoplasma in the nonvector insect Nephotettix cincticeps. Jpn. J. Phytopathol. 2009, 75, 29-34. [CrossRef]

12. Hoy, C.W.; Heady, S.E.; Koch, T.A. Species composition, phenology, and possible origins of leafhoppers (Cicadellidae) in Ohio vegetable crops. J. Econ. Entomol. 1992, 85, 2336-2343. [CrossRef]

13. Whitney, S.P.; Meyer, J.R. Movement between wild and cultivated blueberry by two species of sharpnosed leafhoppers (Homoptera: Cicadellidae) in North Carolina. J. Entomol. Sci. 1988, 23, 88-95. [CrossRef]

14. Mcclure, M.S. Spatial and seasonal distributions of leafhopper vectors of peach X-disease in Connecticut. Environ. Entomol. 1980, 9, 668-672. [CrossRef]

15. Gavloski, J. Leafhoppers in Manitoba; biology, behaviour and potential for vectoring plant diseases. Univ. Manit. Ext. 2007, 1-5. Available online: http://www.umanitoba.ca/faculties/afs/MAC_proceedings/ proceedings/2007/John_Gavloski.pdf (accessed on 28 October 2019).

16. Jubenville, J.J. The Spatial and Temporal Distribution of Arthropods in Michigan Celery Agroecosystems. Master's Thesis, Michigan State University, East Lansing, MI, USA, 2015. Available from ProQuest Dissertations and Theses Global. (UMI No. 1598768). Available online: search.proquest.com/docview/ 1721793332 (accessed on 1 October 2019).

17. Mirzaie, A.; Esmailzadeh-Hosseini, S.A.; Jafari-Nodoshan, A.; Rahimian, H. Molecular characterization and potential insect vector of a phytoplasma associated with garden beet witches? Broom in Yazd, Iran. J. Phytopathol. 2007, 155, 198-203. [CrossRef]

18. Marcone, C.; Ragozzino, A.; Seemüller, E. Detection and identification of phytoplasmas in yellows-diseased weeds in Italy. Plant. Pathol. 1997, 46, 530-537. [CrossRef]

19. Lee, I.-M.; Gundersen-Rindal, D.E.; Bertaccini, A. Phytoplasma: Ecology and genomic diversity. Phytopathology 1998, 88, 1359-1366. [CrossRef]

20. Hebert, P.D.N.; Cywinska, A.; Ball, S.L.; deWaard, J.R. Biological identifications through DNA barcodes. Proc. R. Soc. Lond. B Biol. Sci. 2003, 270, 313-321. [CrossRef]

21. Porter, T.M.; Hajibabaei, M. Over 2.5 million COI sequences in GenBank and growing. PLoS ONE 2018, 13, e0200177. [CrossRef] 
22. Demeuse, K.L.; Grode, A.S.; Szendrei, Z. Comparing qPCR and nested PCR diagnostic methods for aster yellows phytoplasma in aster leafhoppers. Plant Dis. 2016, 100, 2513-2519. [CrossRef]

23. Christensen, N.M.; Nicolaisen, M.; Hansen, M.; Schulz, A. Distribution of phytoplasmas in infected plants as revealed by real-time PCR and bioimaging. Mol. Plant Microbe Interact. 2004, 17, 1175-1184. [CrossRef]

24. Dellaporta, S.L.; Wood, J.; Hicks, J.B. A plant DNA minipreparation: Version II. Plant Mol. Biol. Rep. 1983, 1, 19-21. [CrossRef]

25. Simon, C.; Frati, F.; Beckenbach, A.; Crespi, B.; Liu, H.; Flook, P. Evolution, weighting, and phylogenetic utility of mitochondrial gene sequences and a compilation of conserved polymerase chain reaction primers. Ann. Entomol. Soc. Am. 1994, 87, 651-701. [CrossRef]

26. Bug guide. Available online: https://bugguide.net/node/view/15740 (accessed on 20 November 2019).

27. Duduk, B.; Paltrinieri, S.; Lee, I.-M.; Bertaccini, A. Nested PCR and RFLP analysis based on the 16S rRNA gene. In Phytoplasmas: Methods and protocols, 1st ed.; Dickinson, M., Hodgetts, J., Eds.; Humana: New York, NY, USA, 2013; pp. 159-171. [CrossRef]

28. Lenth, R. Emmeans: Estimated Marginal Means, Aka Least-Squares Means; R package version 1.4.4. 2020.

29. R Core Team R: A Language and Environment for Statistical Computing; R Foundation for Statistical Computing: Vienna, Austria, 2019.

30. Katoh, K.; Standley, D.M. MAFFT multiple sequence alignment software version 7: Improvements in performance and usability. Mol. Biol. Evol. 2013, 30, 772-780. [CrossRef] [PubMed]

31. Stamatakis, A. RAxML version 8: A tool for phylogenetic analysis and post-analysis of large phylogenies. Bioinformatics 2014, 30, 1312-1313. [CrossRef] [PubMed]

32. Miller, M.A.; Pfeiffer, W.; Schwartz, T. Creating the CIPRES Science Gateway for inference of large phylogenetic trees. In Proceedings of the 2010 Gateway Computing Environments Workshop (GCE), New Orleans, LA, USA, 14 November 2010; pp. 1-8. [CrossRef]

33. Brčák, J. Leafhopper and planthopper vectors of plant disease agents in central and southern Europe. In Leafhopper Vectors and Plant Disease Agents, 1st ed.; Maramorosch, K., Ed.; Academic Press: New York, NY, USA, 1979; pp. 97-154.

34. Posnette, A.F.; Ellenberger, C.E. Further studies of green petal and other leafhopper-transmitted viruses infecting strawberry and clover. Ann. Appl. Biol. 1963, 51, 69-83. [CrossRef]

35. Chiykowski, L.N. Athysanus argentarius, an introduced European leafhopper, as a vector of aster yellows in North America. Can. J. Plant Pathol. 1979, 1, 37-41.

36. Gilmer, R.M. Insect transmission of X-disease virus of stone fruits in New York. N.Y. St. Agric. Exp. Stn. Bull. 1966, 813, 1-22.

37. Wolfe, H.R.; Anthon, E.W.; Jones, L.S. Transmission of western X-disease of peaches by the leafhopper, Colladonus geminatus (Van, D.). Phytopathology 1950, 40, 991.

38. Frazier, N.; Severin, H. Weed-host range of California aster yellows. Hilgardia 1945, 16, 619-650. [CrossRef]

39. Wolfe, H.R. Transmission of the Western $X$ disease virus by the leafhopper Colladonus montanus (Van, D.). Plant Rep. 1955, 39, 298-299.

40. Nielson, M.W. Taxonomic relationships of leafhopper vectors of plant pathogens. Leafhopper Vectors and Plant Disease Agents 1979, 3-27. [CrossRef]

41. Hill, G.T.; Sinclair, W.A. Taxa of leafhoppers carrying phytoplasmas at sites of ash yellows occurrence in New York state. Plant Dis. 2000, 84, 134-138. [CrossRef] [PubMed]

42. Chiykowski, L.N.; Sinha, R.C. Comparative efficiency of transmission of aster yellows by Elymana virescens and Macrosteles fascifrons and the relative concentration of the causal agent in the vectors. J. Econ. Entomol. 1969, 62, 883-886. [CrossRef]

43. Olivier, C.Y.; Lowery, D.T.; Stobbs, L.W. Phytoplasma diseases and their relationships with insect and plant hosts in Canadian horticultural and field crops. Can. Entomol. 2009, 141, 425-462. [CrossRef]

44. Chiykowski, L.N. Epidemiology of diseases caused by leafhopper-borne pathogens. In Plant Diseases and Vectors: Ecology and Epidemiology; Academic Press: New York, NY, USA, 1981; pp. 106-142.

45. Sein, F.; Adsuar, J. Transmission of the bunchy top disease of papaya (Carica papaya L.) by the leaf hopper Empoasca papayae Oman. Science 1947, 106, 130. [CrossRef] 
46. Galetto, L.; Marzachì, C.; Demichelis, S.; Bosco, D. Host plant determines the phytoplasma transmission competence of Empoasca decipiens (Hemiptera: Cicadellidae). J. Econ. Entomol. 2011, 104, 360-366. [CrossRef]

47. Acosta, K.I.; Zamora, L.; Piñol, B.; Quiñones, M.L.; Ramos, P.L.; Luis, M.; Leyva-López, N.E.; Arocha, Y. Empoasca papayae Oman, 1937 (Hemiptera: Cicadellidae) the simultaneous vector of phytoplasmas and rickettsia associated with "Bunchy Top Symptom" in Cuba. An. Biol. 2017, 39, 35-42. [CrossRef]

48. Chiykowski, L.N. Endria inimica (Say), a new leafhopper vector of a celery-infecting strain of aster-yellows virus in barley and wheat. Can. J. Bot. 1963, 41, 669-672. [CrossRef]

49. Hamilton, K.G.A. Introduced and native leafhoppers common to the old and new worlds (Rhynchota: Homoptera: Cicadellidae). Can. Entomol. 1983, 115, 473-511. [CrossRef]

50. Khadhair, A.-H.; Hiruki, C.; Hwang, S.F. Molecular detection of alfalfa witches'-broom phytoplasma in four leafhopper species associated with infected alfalfa plants. Microbiol. Res. 1997, 152, 269-275. [CrossRef]

51. Lenzi, P.; Stoepler, T.M.; McHenry, D.J.; Davis, R.E.; Wolf, T.K. Jikradia olitoria ([Hemiptera]:[Cicadellidae]) transmits the sequevar NAGYIII $\beta$ phytoplasma strain associated with North American Grapevine Yellows in artificial feeding assays. J. Insect Sci. 2019, 19. [CrossRef] [PubMed]

52. Gilmer, R.M. Insect transmission of X-disease virus in New York. Plant Dis. Rep. 1954, 38, 628-629.

53. Esau, K.; Magyarosy, A.C.; Breazeale, V. Studies of the mycoplasma-like organism (MLO) in spinach leaves affected by the aster yellows disease. Protoplasma 1976, 90, 189-203. [CrossRef]

54. Batlle, A.; Altabella, N.; Sabaté, J.; Laviña, A. Study of the transmission of stolbur phytoplasma to different crop species, by Macrosteles quadripunctulatus. Ann. Appl. Biol. 2008, 152, 235-242. [CrossRef]

55. Guclu, S.; Ozbek, H. Studies on the vectors of MLOs caused stolbur disease of potatoes in Erzurum. Atatürk Üniversitesi Ziraat Fakültesi Dergisi 1991, 22, 35-42.

56. Palermo, S.; Arzone, A.; Bosco, D. Vector-pathogen-host plant relationships of chrysanthemum yellows (CY) phytoplasma and the vector leafhoppers Macrosteles quadripunctulatus and Euscelidius variegatus. Entomol. Exp. Appl. 2001, 99, 347-354. [CrossRef]

57. Van Slogteren, D.H.M.; Muller, P.J. "lissers", a yellows disease in hyacinths, apparently caused by a Mycoplasma. Ghent Rijksfac Landbouwetensch Meded 1972, 37, 450-457.

58. Savio, C.; Conti, M. Epidemiology and transmission of plant mycoplasmas. In Proceedings of the Atti XIII Congresso Nazionale Italiano di Entomologia, Istituto di Entomologia Agraria e Apicoltura, Università di Torino, Turin, Italy, 27 June-1 July 1983; pp. 407-414.

59. Kato, S.; Iwanami, S.; Tezuka, N. Occurrence and host range of anemone (Anemone coronaria L.) witches' broom in Shizuoka Prefecture. Jpn. J. Phytopathol. 1989, 55, 64-66. [CrossRef]

60. Okuda, S.; Prince, J.P.; Davis, R.E.; Dally, E.L.; Lee, I.-M.; Mogen, B.; Kato, S. Two groups of phytoplasmas from Japan distinguished on the basis of amplification and restriction analysis of $16 \mathrm{~S}$ rDNA. Plant Dis. 1997, 81, 301-305. [CrossRef]

61. Shiomi, T.; Sugiura, M. Difference among Macrosteles orientalis-transmitted MLO, potato purple-top wilt MLO in Japan and aster yellows MLO from USA. Jpn. J. Phytopathol. 1984, 50, 455-460. [CrossRef]

62. Oshima, K.; Shiomi, T.; Kuboyama, T.; Sawayanagi, T.; Nishigawa, H.; Kakizawa, S.; Miyata, S.; Ugaki, M.; Namba, S. Isolation and characterization of derivative lines of the onion yellows phytoplasma that do not cause stunting or phloem hyperplasia. Phytopathology 2001, 91, 1024-1029. [CrossRef] [PubMed]

63. Kato, S.; Shiomi, T.; Wakibe, H.; Iwanami, S. Tomato yellows transmitted by the leafhopper vector, Macrosteles orientalis Virbaste. Jpn. J. Phytopathol. 1988, 54, 220-223. [CrossRef]

64. Frazier, N.W.; Posnette, A.F. Leafhopper transmission of a clover virus causing green petal disease in strawberry. Nature 1956, 177, 1040-1041. [CrossRef]

65. Heu, R.A.; Kumashiro, B.R.; Hamasaki, R.T.; Fukuda, S.K. Watercress leafhopper Macrosteles sp. nr. severini Hamilton (Homoptera: Cicadellidae). Hawaii Dep. Agric. Pest. Advis. 2003, 1-2. Available online: http://www.hawaiiag.org/hdoa/npa/npa02-01-wcleafhopper.pdf (accessed on 28 October 2019).

66. An, D.R.; Wei, N.S.; Zhang, Q.F.; Zhang, R.; Zhu, X. The primary report of wheat mycoplasma like-organism blue dwarf disease (WNBD). Acta Phytophylac Sin. 1991, 21, 263-266.

67. Sinha, R.C.; Chiykowski, L.N. Multiplication of aster yellows virus in a nonvector leafhopper. Virology 1967, 31, 461-466. [CrossRef] 
68. Beanland, L.; Wolf, T. Possible insect vectors of North American grapevine yellows phytoplasma in Virginia. In Proceedings of the 14th Conference of the International Council for the Study of Virus and Virus-like Diseases of the Grapevine, Locorotondo, Italy, 12-17 September 2003; pp. 12-17.

69. Pantoja, A.; Hagerty, A.M.; Emmert, S.Y.; Munyaneza, J.E. Leafhoppers (Homoptera: Cicadellidae) associated with potatoes in Alaska: Species composition, seasonal abundance, and potential phytoplasma vectors. Am. J. Potato Res. 2009, 86, 68-75. [CrossRef]

70. Rosa, C.; McCarthy, E.; Duong, K.; Hoover, G.; Moorman, G. First report of the spittlebug Lepyronia quadrangularis and the leafhopper Latalus sp. as vectors of the elm yellows associated phytoplasma, Candidatus Phytoplasma ulmi in North America. Plant Dis. 2013, 98, 154. [CrossRef]

71. Chiykowski, L.N. Vector-pathogen-host plant relationships of clover phyllody mycoplasmalike organism and the vector leafhopper Paraphlepsius irroratus. Can. J. Plant Pathol. 1991, 13, 11-18. [CrossRef]

72. Derrick, K.S.; Newsom, L.D. Occurrence of a leafhopper-transmitted disease of soybeans in Louisiana [Scaphytopius acutus, possible mycoplasmal disease, soybean bud proliferation, insect vectors]. Plant Dis. USA 1984, 68, 343-344. [CrossRef]

73. Severin, H.H.P. Newly discovered leafhopper vectors of California aster-yellows virus. Hilgardia 1947, 17, 511-523. [CrossRef]

74. Purcell, A.H.; Suslow, K.G. Pathogenicity and effects on transmission of a mycoplasmalike organism of a transovarially infective bacterium on the leafhopper Euscelidius variegatus (Homoptera: Cicadellidae). J. Invertebr. Pathol. 1987, 50, 285-290. [CrossRef]

75. Granada, G.A. Machismo disease of soybeans. I. Symptomatology and transmission [Leafhopper Scaphytopius fuliginosus as insect vector, mycoplasma-like diseases, Colombia]. Plant Dis. Rep. 1979, 63, 47-50.

76. Howard, F.W.; Thomas, D.L. Transmission of palm lethal decline to Veitchia merrillii by a planthopper Myndus crudus. J. Econ. Entomol. 1980, 73, 715-717. [CrossRef]

77. Purcell, A.H. Transmission of X-disease agent by the leafhoppers Scaphytopius nitridus and Acinopterus angulatus. Plant Dis. Rep. 1979, 63, 549-552.

78. Frost, K.E.; Esker, P.D.; Van Haren, R.; Kotolski, L.; Groves, R.L. Seasonal patterns of aster leafhopper (Hemiptera: Cicadellidae) abundance and aster yellows phytoplasma infectivity in Wisconsin carrot fields. Environ. Entomol. 2013, 42, 491-502. [CrossRef]

79. Chiykowski, L.N. Transmission of a celery-infecting strain of aster yellows by the leafhopper Aphrodes bicinctus. Phytopathology 1977, 67, 522-524. [CrossRef]

80. Chiykowski, L.N. Scaphytopius acutus (Say), a newly discovered vector of celery-infecting aster-yellows virus. Can. J. Bot. 1962, 40, 799-801. [CrossRef]

81. Vega, F.E.; Davis, R.E.; Barbosa, P.; Dally, E.L.; Purcell, A.H.; Lee, I.-M. Detection of a plant pathogen in a nonvector insect species by the polymerase chain reaction. Phytopatholgy 1993, 83, 621-624. [CrossRef]

82. Tanne, E.; Boudon-Padieu, E.; Clair, D.; Davidovich, M.; Melamed, S.; Klein, M. Detection of Phytoplasma by Polymerase Chain Reaction of Insect Feeding Medium and Its Use in Determining Vectoring Ability. Phytopathology 2001, 91, 741-746. [CrossRef]

83. Olivier, C.Y.; Séguin-Swartz, G.; Galka, B.; Olfert, O.O. Aster yellows in leafhoppers and field crops in Saskatchewan, Canada, 2001-2008. Am. J. Plant Sci. Biotechnol. 2011, 141, 425-462.

84. Pérez, K.A.; Piñol, B.; Rosete, Y.A.; Wilson, M.; Boa, E.; Lucas, J. Transmission of the phytoplasma associated with Bunchy Top Symptom of papaya by Empoasca papayae Oman. J. Phytopathol. 2010, 158, 194-196. [CrossRef]

85. USDA NASS National Agricultural Statistics Service. Available online: https://www.nass.usda.gov/ (accessed on 9 January 2020).

86. Sharon, R.; Soroker, V.; Wesley, S.D.; Zahavi, T.; Harari, A.; Weintraub, P.G. Vitex agnus-castus is a preferred host plant for Hyalesthes obsoletus. J. Chem. Ecol. 2005, 31, 1051-1063. [CrossRef] [PubMed]

87. Szendrei, Z. The impact of plant associations on Macrosteles quadrilineatus management in carrots: Plant association effects on leafhoppers. Entomol. Exp. Appl. 2012, 143, 191-198. [CrossRef]

88. Stillson, P.T.; Bloom, E.H.; Gutierrez Illan, J.; Szendrei, Z. A novel plant pathogen management tool for vector management. Pest. Manag. Sci. 2020. [CrossRef] 
89. Poos, F.W.; Wheeler, N.H. Studies on host plants of the leafhoppers of the genus Empoasca'. In US Dep. Agric. Tech. Bull. 850; 1943. Available online: https://naldc.nal.usda.gov/download/CAT86200843/PDF (accessed on 28 October 2019).

90. Delahaut, K.A. Aster leafhopper. Univ. Wis. Ext. Bull. 1997, 1-4. Available online: https://vegento. russell.wisc.edu/wp-content/uploads/sites/249/2017/03/Aster-leafhopper-A3679-1997.pdf (accessed on 28 October 2019).

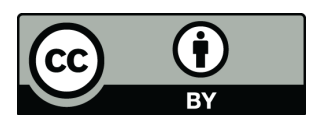

(C) 2020 by the authors. Licensee MDPI, Basel, Switzerland. This article is an open access article distributed under the terms and conditions of the Creative Commons Attribution (CC BY) license (http://creativecommons.org/licenses/by/4.0/). 